\title{
Hasil Penelitian
}

\section{UJI DAYA HAMBAT EKSTRAK BIJI PINANG (Arecha catechu L.) TERHADAP PERTUMBUHAN Streptococcus mutans SECARA IN VITRO}

\author{
Yuniasih MJ Taihuttu \\ Program Pendidikan Dokter Universitas Pattimura Ambon \\ E-mail : yuni.taihuttu@gmail.com, HP : 0811473683
}

\begin{abstract}
Abstrak
Pendahuluan: Telah diuji daya hambat ekstrak biji pinang (Areca catechu L.) terhadap pertumbuhan bakteri Streptococcus mutans (S. mutans) secara in vitro. Tujuan: mengetahui kemampuan daya hambat ekstrak biji pinang terhadap pertumbuhan $S$. mutans Metode: Biji pinang diekstraksi dengan menggunakan pelarut etanol dan air. Pengaruh berupa zona penghambatan pertumbuhan bakteri akan tampak melalui difusi lempeng agar. Hasil: Ekstrak biji pinang efektif menghambat pertumbuhan $S$. mutans. Ekstrak etanol terbukti lebih efektif dalam menghambat $S$. mutans dibandingkan dengan ekstrak air. Konsentrasi hambat minimun (KHM) untuk ekstrak etanol biji pinang diperoleh pada konsentrasi $0,005 \%$ (w/v) dengan rerata zona hambat sebesar $0,67 \mathrm{~mm}$. Sedangkan 0,75\% merupakan konsentrasi terkecil dalam menghambat $S$. mutans pada ekstrak air biji pinang dengan rerata diameter sebesar 3,23 mm. Uji kromatografi lapis tipis (KLT) pada ekstrak etanol biji pinang telah menemukan 4 fraksi senyawa dengan nilai Rf 0,122; 0,300; 0,472 dan 0,0705. Spesifikasi senyawa tersebut tidak diidentifikasi dalam penelitian ini. Kesimpulan: Ekstrak biji pinang terbukti efektif menghambat pertumbuhan bakteri $S$. mutans.
\end{abstract}

Kata Kunci: Areca catechu L, ekstrak air, ekstrak etanol, konsentrasi hambat minimum Streptococcus mutans,

\section{THE INHIBITION ACTIVITIES OF ARECA NUT EXTRACT (Arecha catechu L.) TOWARDS Streptococcus mutans IN VITRO}

\begin{abstract}
Introduction. Inhibition activities of areca nut (Areca catechu L) extracts towards Streptococcus mutans has been tested. Ethanol and water solvent extracts were used. Methods. The effects shown by the inhibition zone were carried out using agar diffusion method. Results. The result showed that ethanol extract had more effective inhibiting the growth of $S$. mutans compared with water extract. The minimal inhibition concentration (MIC) of the ethanol extracts against $S$. mutans was found in the level of 0,05\% (w/v) with inhibition zone 0,67 mm. Meanwhile, 0,75\% was the MIC of water areca nut extracts with 3,23 mm zone of inhibition. Thin layer chromatography (TLC) test of ethanol areca nut extracts showed 4 fractions. The $R f$ value of those fractions were 0,122;0,300;0,472 and 0,705. However, these kind of fractions were unidentifying in this study. Conclusion. Areca catechu L. extracts were effective to inhibit the growth of Streptococcus mutans.
\end{abstract}

Keywords: Areca catechu L., extracts, minimun inhibition concentration, Streptococcus mutans 


\section{Pendahuluan}

Pinang telah menjadi tanaman yang umum dijumpai pada daerah Asia Tenggara. Pinang juga digunakan oleh para imigran di Eropa, Afrika dan Amerika Utara. Secara sosial, penggunaan biji pinang dan daun sirih telah diterima di semua lapisan masyarakat melalui aktivitas menyirih. Aktivitas menyirih merupakan kombinasi dari daun sirih (Piper bettle), biji pinang (Areca catechu L) dan kapur sirih. Biji pinang yang digunakan dalam tradisi menyirih merupakan bahan psikoaktif yang paling umum di dunia setelah kafein, alkohol dan nikotin ${ }^{1}$. Beberapa penelitian telah dilakukan untuk melihat kandungan kimia dari beberapa tanaman yang berfungsi untuk menjaga kesehatan gigi. Miller and Hamilton ${ }^{2}$ melaporkan penelitian yang menunjukan tentang adanya kandungan katekin dan terpen yang terkandung dalam teh hijau (Camilia sinensis) untuk digunakan dalam aktivitas antikariogenik. Hutchings et al dalam Lin et $\mathrm{al}^{3}$ menemukan bahwa Chypostemma lanigerum berkhasiat dalam terapi sakit gigi. Biji pinang telah dilaporkan mengandung alkaloid seperti arekolin $\left(\mathrm{C}_{8} \mathrm{H}_{13} \mathrm{NO}_{2}\right)$, arekolidin, arekain, guvakolin, guvasin dan isoguvasin. Selain itu juga mengandung tanin merah, lemak (palmitik, olaik, stearik, kaproik, kaprilik, laurik dan myristik), kanji dan resin. Masduki ${ }^{4}$ telah melaporkan hasil penelitiannya tentang dugaan keefektifan senyawa tanin biji pinang dalam menghambat bakteri Staphylococcus aureus. Ekstrak pinang mampu menghambat pertumbuhan, perlekatan dan sintesis matriks protein pada fibroblast gingival manusia. Salah satu bakteri penyebab kerusakan gigi adalah Streptococcus mutans. (S. mutans) merupakan bakteri patogen pada mulut yang merupakan agen utama penyebab timbulnya plak, gingivatis dan karies gigi ${ }^{5}$. S. mutans mampu menyebabkan karies gigi melalui beberapa tahapan antara lain, perlekatan pada gigi melalui fimbria bakteri. Pembentukan glikokaliks karena adanya sintesis glukan melalui kerja enzim glukosiltransferase pada sukrosa dan akumulasi biofilm dalam plak yang mengandung bakteri penghasil asam ${ }^{2}$. Dalam penelitian ini S. mutans dijadikan sebagai mikroba uji untuk melihat efektivitas ekstrak etanol dan air biji pinang terhadap bakteri patogen mulut melalui difusi lempeng agar. 


\section{Metode}

Penelitian ini merupakan penelitian laboratorium untuk menguji besar daya hambat esktrak biji pinang pada berbagai konsentrasi untuk mengetahui konsentrasi hambat minimum (KHM).

\section{Alat dan Bahan}

Alat yang digunakan adalah autoklaf, batang pengaduk, bejana maserasi, botol gelap, cawan Petri, Erlenmeyer, gelas ukur, inkubator, kaliper, Laminar Air Flow, labu ukur, lampu UV 254 nm, oven, pipet mikro, rotavapor, spektrofotometer, silinder logam, spatula, syringe, tabung reaksi dan lumpang.

Bahan yang digunakan adalah biakan murni $S$. mutans, pinang putih, nutrien agar, glukosa nutrien agar, aquades, alkohol 70\%, etanol absolut, larutan $\mathrm{NaCl}$ 0,9\%, natrium klorida, silika gel $60 \mathrm{GF}_{254}$ dan spiritus.

\section{Prosedur Penelitian}

Tahap Persiapan

a. Sterilisasi alat dan bahan

Semua alat gelas yang akan dipakai, dicuci bersih dan dibungkus dengan kertas. Media nutrien agar dan nutrien broth, glukosa nutrien agar dan semua alat gelas, disterilisasi menggunakan autoklaf selama 15 menit dengan tekanan $1 \mathrm{~atm} 121^{\circ} \mathrm{C}$.

b. Ekstraksi biji pinang

Pembuatan ekstrak etanol biji pinang

Biji pinang yang akan diekstraksi dengan metode maserasi, dicuci bersih dan dikeringanginkan pada tempat yang tidak terkena matahari langsung sambil sering dibolakbalik untuk meratakan pengeringannya. Setelah kering, sampel dipotong kecil untuk dibuat serbuk. Serbuk biji pinang ditimbang seberat $250 \mathrm{~g}$, dimasukan ke dalam bejana maserasi lalu direndam dengan etanol absolut sampai semua simplisia terendam. Dibiarkan 5 hari pada tempat terlindung dari cahaya matahari, sambil sekali-kali diaduk. Setelah lima hari, hasil maserasi disaring dan ampasnya diperas. Perlakuan ini dilakukan sebanyak tiga kali. Ekstrak cair yang diperoleh ditampung dalam labu Erlenmeyer lalu diuapkan dengan rotavapor untuk memperoleh ekstrak kental, kemudian diuapkan lagi di atas penangas air untuk memperoleh ekstrak etanol kering $^{6}$. 
Pembuatan stok konsentrasi

Stok konsentrasi ekstrak biji pinang yang akan digunakan divariasikan mulai dari aquades (kontrol negatif), 2,5\% (w/v), 2\%, 1,5\%, 1\%, $0,75 \%, 0,5 \%, 0,25 \%, 0,1 \%, 0,075 \%, 0,06 \%$, $0,05 \%, \quad 0,04 \%, 0,01 \%, 0,0075 \%, 0,005 \%$, 0,0025\% dan tetracyclin $30 \mu \mathrm{g} / \mathrm{mL}$ (kontrol positif).

a. Pembuatan medium ${ }^{7}$

Medium yang disiapkan untuk digunakan adalah medium pertumbuhan biasa yaitu nutrien agar (NA) dan medium glukosa nutrien agar (GNA). semua bahan dicampur dalam Erlenmeyer $100 \mathrm{~mL}$ dan ditambahkan aquades $50 \mathrm{~mL}$. Kemudian dipanaskan hingga larut di atas penangas air dan diukur $\mathrm{pH}$ pada 7,0 menggunakan indikator universal. Setelah itu disterilkan dalam autoklaf pada suhu $121^{\circ} \mathrm{C}$ selama 15 menit.

b. Penyiapan bakteri $^{7}$

Peremajaan kultur murni bakteri uji

Bakteri uji berupa biakan murni S. mutans diambil satu ose kemudian diinokulasikan dengan cara digores pada medium nutrien agar miring selanjutnya diinkubasikan pada suhu
$37^{0} \mathrm{C}$ selama 24 jam.

Penyiapan suspensi bakteri uji

Bakteri uji yang berumur 24 jam dari agar miring disuspensikan dalam larutan $\mathrm{NaCl} 0,9 \%$ steril menggunakan ose bulat untuk selanjutnya diukur dengan spektrofotometer dengan nilai transmitans $25 \%^{7}$. Suspensi inilah yang digunakan sebagai mikroba uji. Sebagai blanko digunakan larutan $\mathrm{NaCl} \quad 0,9 \%$ steril dengan panjang gelombang $580 \mathrm{~nm}$. Satu mililiter suspensi bakteri akan diinokulasikan pada media glukosa nutrien agar sebanyak 10 $\mathrm{mL}$.

\section{Tahap Pengujian}

a. Penentuan diameter hambatan dengan metode difusi agar ${ }^{8}$

Medium GNA steril didinginkan hingga suhu 40$45^{\circ} \mathrm{C}$ kemudian dituang secara aseptis ke dalam cawan Petri sebanyak $15 \mathrm{~mL}$ dan dibiarkan memadat sebagai lapisan dasar (base layer). Setelah itu, 10 mL medium GNA dicampur dengan $1 \mathrm{~mL}$ suspensi bakteri yang telah diukur nilai transmitansnya, kemudian dituang di atas medium GNA yang telah memadat tadi dan dibiarkan hingga setengah memadat, kemudian diletakan 
silinder logam dengan diameter dalam $6 \mathrm{~mm}$ dan tinggi $10 \mathrm{~mm}$. Jarak tiap silinder diatur $3 \mathrm{~cm}$ dan jarak silinder dengan tepi media $2 \mathrm{~cm}$. Tiap silinder diisi dengan ekstrak etanol biji pinang yang telah disiapkan dengan konsentrasi masing-masing $2,5 \%(\mathrm{w} / \mathrm{v}), 2 \%, 1,5 \%, 1 \%, 0,75 \%, 0,5 \%, 0,25 \%$, $0,1 \%, 0,075 \%, 0,06 \%, 0,05 \%, 0,04 \%, 0,01 \%$ $0,0075 \%, 0,005 \%, 0,0025 \%$. Hal ini berlaku pula pada ekstrak air biji pinang. Dilakukan 3 kali repetisi. Silinder logam yang berfungsi sebagai kontrol negatif hanya ditetesi dengan aquades steril. Antibiotik standar sebagai kontrol positif adalah tetracyclin $30 \mu \mathrm{g} / \mathrm{mL}$. Kultur selanjutnya diinkubasikan dalam inkubator. Inkubasi dilakukan selama 24 jam pada suhu $37^{\circ} \mathrm{C}$, kemudian diukur diameter zona terang menggunakan kaliper. Zona penghambatan dalam bentuk diameter zona bebas pertumbuhan dicatat pada akhir periode inkubasi.

b. Pengujian dengan metode kromatografi lapis tipis $^{9}$

Pengujian ini dimaksudkan untuk mengetahui jumlah fraksi yang ada pada ekstrak biji pinang. Silika gel $60 \mathrm{GF}_{254}$ digunakan sebagai bahan penguji ekstrak biji pinang. Eluen berupa larutan etanol absolut dimasukkan dalam chamber dan ditutup. Ekstrak biji pinang ditotolkan pada plat KLT dengan pipa kapiler dan dibiarkan kering di udara. Plat ini kemudian dimasukkan dalam chamber dan biarkan eluen terelusi hingga kirakira $3 / 4$ dari tinggi plat KLT (atau diberi garis sebelumnya). Komponen senyawa dalam ekstrak biji pinang berupa spot selanjutnya akan diamati di bawah lampu UV $254 \mathrm{~nm}$ dan dihitung $\mathrm{Rf}$ (retardation factor).

\section{Hasil}

A. Hasil ekstraksi biji pinang

Setelah dilakukan esktraksi biji pinang sebanyak 250 g secara maserasi dengan pelarut, maka diperoleh 4,0 gram ekstrak etanol kental dan 4,2 gram ekstrak air biji pinang.

B. Hasil pengujian esktrak biji pinang

Hasil pengukuran diameter hambatan ekstrak terhadap pertumbuhan $S$. mutans. 
Tabel 2. Rata-rata Diameter Hambatan Ekstrak Air dan Ekstrak Etanol Biji Pinang

\begin{tabular}{ccc}
\hline $\begin{array}{c}\text { Konsentrasi } \\
(\%)\end{array}$ & $\begin{array}{c}\text { Rata-Rata } \\
\text { Diameter } \\
\text { Hambatan Ekstrak } \\
\text { Air }(\mathbf{m m})\end{array}$ & $\begin{array}{c}\text { Rata-Rata } \\
\text { Diameter } \\
\text { Hambatan } \\
\text { Ekstrak Etanol } \\
(\mathbf{m m})\end{array}$ \\
\hline 0,0025 & 0,00 & 0,00 \\
0,005 & 0,00 & 0,67 \\
0,075 & 0,00 & 1,43 \\
0,01 & 0,00 & 3,33 \\
0,04 & 0,00 & 6,50 \\
0,05 & 0,00 & 7,27 \\
0,06 & 0,00 & 7,83 \\
0,075 & 0,00 & 8,30 \\
0,1 & 0,00 & 8,83 \\
0,25 & 0,00 & 9,53 \\
0,5 & 0,00 & 10,13 \\
0,75 & 3,23 & 10,94 \\
1 & 3,50 & 11,48 \\
1,5 & 3,77 & 12,40 \\
2 & 3,84 & 12,83 \\
2,5 & 5,00 & 13,50 \\
\hline
\end{tabular}

Rerata diameter zona berkisar antara 0-5,00 mm.

Ekstrak air biji pinang telah memperlihatkan keefektifannya pada konsentrasi $0,75 \%$ dengan rerata diameter 3,23 $\mathrm{mm}$. Dengan demikian konsentrasi ini merupakan KHM ekstrak air biji pinang. Sedangkan KHM etanol biji pinang terletak pada konsentrasi $0,005 \%$ dengan besar diameter adalah 0,67 mm. Diameter zona hambat ini mulai meningkat dengan pertambahan konsentrasi ke level yang lebih besar (Gambar 1).

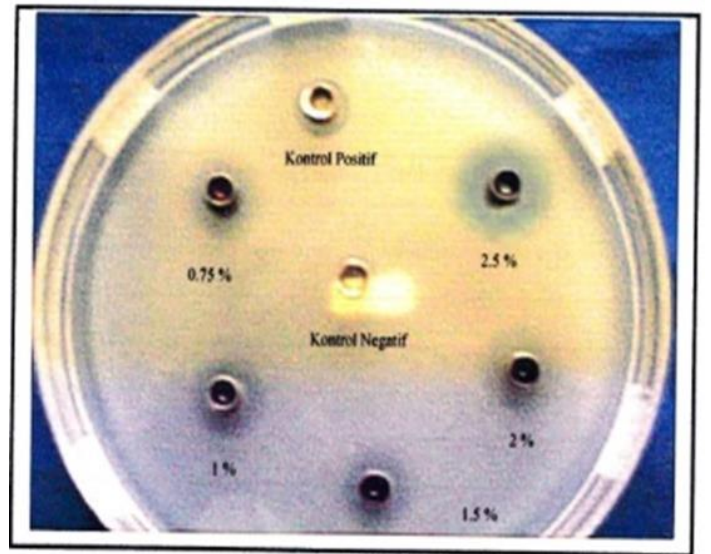

Gambar 1. Diameter hambatan ekstrak air biji pinang. Sumuran yang diisi dengan ekstrak air memberi hambatan pada pertumbuhan bakteri $S$. mutans sebesar $5 \mathrm{~mm}$ ([2,5\%]). KHM pada ekstrak air ini adalah pada ] konsentrasi ekstrak 0,75\%

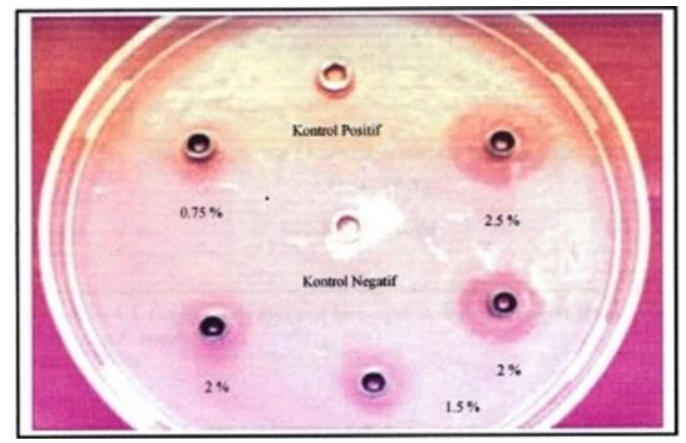

Gambar 2. Diameter hambatan ekstrak etanol biji pinang. Ekstrak etanol telah diketahui menghambat pertumbuhan bakteri $S$. mutans pada konsentrasi $0,005 \%$. Pada konsentrasi yang sama dengan ekstrak air (2,5\%), ekstrak etanol telah memperlihatkan diameter hambatan yang lebih besar yaitu 13,50 $\mathrm{mm}$.

Perbandingan konsentrasi daya hambat ekstrak air dan etanol biji pinang diperlihatkan pada gambar 3. Ekstrak etanol diketahui memiliki daya hambat yang lebih besar pada konsentrasi yang sama dengan ekstrak air. 


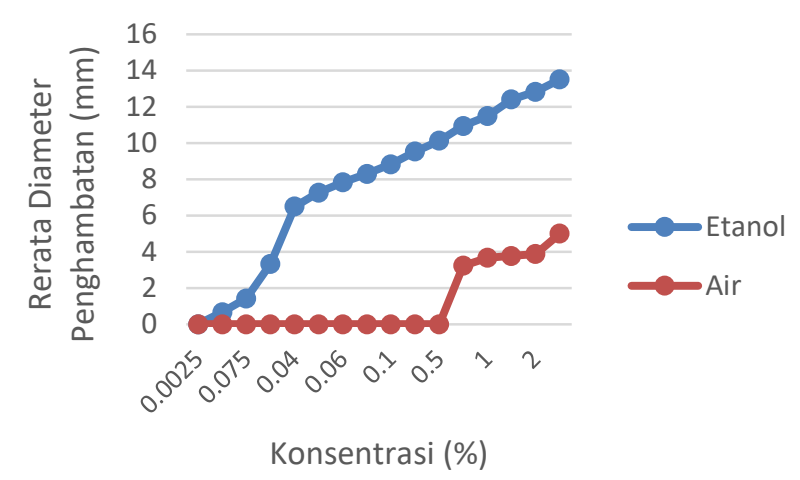

Gambar 3. Grafik penghambatan pertumbuhan S. mutans pada ekstrak air dan etanol biji pinang. Ekstrak etanol telah mulai memperlihatkan keefektifannya pada konsentrasi 0,0025\%, sementara ekstrak air pada konsentrasi 0,05\%. Dengan demikian kedua konsentrasi ini merupakan KHM dari masingmasing konsentrasi. Pada konsentrasi 2,5\% ekstrak air memiliki diameter penghambatan yang lebih kecil $(5 \mathrm{~mm})$ dibandingkan ekstrak etanol $(13,50 \mathrm{~mm})$.

\section{Pembahasan}

Biji pinang adalah tanaman herbal psikoaktif yang penggunaannya menempati urutan keempat terbanyak di dunia. ${ }^{10}$ Biji pinang telah dilaporkan memiliki banyak efek bagi kesehatan diantara sebagai antidepresi ${ }^{10}$, meningkatkan daya belajar dan mengingat $^{11}$ juga memiliki efek antifungal ${ }^{12}$. Penelitian ini dimaksudkan untuk melihat efek antibakteri ekstrak biji pinang terhadap pertumbuhan $S$. mutans.

Beberapa penelitian telah melaporkan adanya efek antibakteri biji pinang pada organisme dan konsentrasi yang berbeda. Masduki ${ }^{4}$ lewat penelitian uji antibakteri ekstrak biji pinang terhadap bakteri Staphylococcus aureus dan Escherichia coli menggunakan teknik sumuran Kirby Bauer membuktikan bahwa ekstrak air biji pinang pada konsentrasi $20 \mathrm{~g} \%$ terhadap bakteri S. aureus mampu menghasilkan ratarata diameter hambatan sebesar $6 \mathrm{~mm}$ sedangkan sediaan infusa menghasilkan 8,33 mm terhadap S. aureus. Namun, tidak didapatkan zona hambatan pada bakteri E. coli pada konsentrasi yang sama. Bila dibandingkan dengan penelitian biji pinang ini, ternyata pada konsentrasi kurang dari $20 \mathrm{~g} \%$, esktrak air biji pinang telah mampu menghambat bakteri uji sebesar 5,00 mm. Uji aktivitas antimikroba biji jintan hitam terhadap bakteri $S$. mutans telah dilakukan oleh Iftitah ${ }^{14}$ dengan menggunakan pelarut metanol. Hasil penelitiannya menunjukkan adanya aktivitas antimikroba yang ditunjukkan oleh besarnya diameter daerah hambatan terbesar pada konsentrasi $1 \%$ sebesar 12,35 mm. Diameter daerah hambatan yang dihasilkan oleh ekstrak biji pinang terhadap S. mutans memiliki nilai yang lebih besar dari penelitian Masduki dan Iftitah di atas. Pada konsentrasi kurang dari 
$20 \%$, ekstrak biji pinang telah menghasilkan

diameter daerah hambatan sebesar 13,5 $\mathrm{mm}$.

Sedangkan pada konsentrasi $1 \%$ saja pada ekstrak etanol biji pinang telah didapatkan diameter sebesar 11,48 mm dan 3,67 mm untuk esktrak air. Rahman et al. ${ }^{15}$ yang melakukan penelitian terhadap bakteri $S$. mutans melaporkan bahwa efek antimikroba dari biji pinang yang diekstraksi menggunakan etanol menghasilkan KHM pada 0,188-0,377 mg/ml. Sementara untuk ekstrak air konsentrasi hambat minimal yang didapatkan berada pada level $0,047-1,56 \mathrm{mg} / \mathrm{ml}$. Isolasi komponen tanaman terutama tergantung pada jenis pelarut yang digunakan dalam prosedur ekstrak. Hal ini dikuatkan oleh Rahman et al yang menyatakan bahwa dari pelarut heksana, air dan etanol yang digunakan sebagai bahan ekstraksi biji pinang, hanya etanol dan air saja yang memberikan efek antimikroba, sementara heksana tidak memberikan efek apapun. Masyarakat pengguna obat-obatan tradisional lebih banyak menggunakan air sebagai pelarut $^{3}$. Zhou ${ }^{15}$ dalam penelitiannya telah membandingkan penghambatan minimum ekstrak air dan etanol licorice terhadap bakteri

S. mutans dan Porph gingivalis yang menunjukkan bahwa esktrak etanol licorice lebih efektif pada konsentrasi $0,062 \mathrm{mg} / \mathrm{mL}$ dan $0,031 \mathrm{mg} / \mathrm{mL}$ dibandingkan dengan ekstrak air licorice yang tidak memperlihatkan adanya zona penghambatan. Lin $e t a l^{3}$ juga menggunakan dua pelarut ekstrak yang berbeda, yaitu pelarut air dan metanol. Penelitiannya menunjukkan bahwa ekstrak metanol memberikan efek antimikroba yang konsisten dibandingkan dengan pelarut air yang lebih banyak digunakan oleh kaum tradisional. Hal ini ditunjukkan melalui hasil penelitian terhadap beberapa jenis bakteri gram yang berbeda dan hasil diameter daerah penghambatan yang lebih besar oleh bakteri gram positif dibandingkan bakteri gram negatif. Rahim dan Khan ${ }^{16}$ juga membuktikan bahwa ekstrak dengan pelarut metanol lebih berpotensi memiliki komponen aktif yang lebih banyak bila dibandingkan dengan ekstrak air. Grafik di atas menunjukkan kemampuan penghambatan ekstrak etanol biji pinang yang lebih optimum dibandingkan dengan ekstrak 
air biji pinang. Hal ini disebabkan karena ekstrak yang dibuat dengan pelarut etanol memungkinkan fraksi yang mengandung zat antibakteri akan lebih banyak terlarut bila dibandingkan dengan ekstrak menggunakan pelarut air. Hal ini menjelaskan bahwa dalam konsentrasi yang kecil, esktrak etanol biji pinang telah mampu menghambat pertumbuhan bakteri $S$. mutans dengan ratarata diameter terkecil pada daerah hambat minimum ialah $0,67 \mathrm{~mm}$. Haryastuti dalam penelitiannya melaporkan kepadatan terkecil bakteri ada pada ekstrak biji pinang dibandingkan dengan kelompok kontrol negatif yang diberi air. Hal ini membuktikan bahwa ekstrak biji pinang memiliki efek antibakteri.

Kandungan ekstrak etanol biji pinang

Hasil Uji Kromatografi Lapis Tipis esktrak etanol, dengan pengembang etanol absolut dengan noda lampu UV 254 nm menunjukan empat fraksi dengan nilai Rf seperti pada tabel di bawah ini :

\begin{tabular}{|c|c|c|c|c|}
\hline No & Fraksi & $\begin{array}{c}\text { Tinggi } \\
(\mathbf{c m})\end{array}$ & $\begin{array}{c}\text { Batas } \\
\text { Elusi } \\
\text { (cm) }\end{array}$ & Rf \\
\hline 1 & A & 1,1 & \multirow{2}{*}{9} & 0,122 \\
\hline 2 & B & 2,7 & & 0,300 \\
\hline 3 & C & 4,25 & & 0,472 \\
\hline 4 & D & 6,35 & & 0,705 \\
\hline
\end{tabular}

Keoptimuman kemampuan penghambatan oleh esktrak etanol biji pinang diduga karena adanya fraksi-fraksi di atas. Namun, tidak diketahui jenis fraksi tersebut dalam penelitian ini dan kemampuan penghambatan tiap fraksi terhadap S. mutans. Menurut Saaroni dan Adjirni $^{17}$, spesifikasi simplisia esktrak etanol biji pinang berwarna coklat kemerahan rasa pahit, kental, mengandung alkaloid, saponin, tanin, flavonoid, polifenol dan antrakinon. Zhou $^{15}$ dalam penemuannya menjelaskan bahwa A. catechu L merupakan salah satu jenis tanaman yang mengandung turunan polifenol yaitu katekin selain tanaman Acacia catecha dan Camelian spp. Selain itu penelitiannya terhadap ekstrak licorice menemukan senyawa turunan polifenol dan ekstrak licorice mengandung efek antimikroba yang lemah namun dapat meningkat jika komponen kimia yang terkandung di dalamnya disatukan. Fine 
dalam Hasryastuti melaporkan bahwa ekstrak

biji pinang mengandung proanstosianidin yang memiliki efek antibakteru. Menurut Masduki ${ }^{4}$, biji pinang mengandung senyawa alkaloid $1,45 \%$ dan terutama sekitar $15 \%$ yang memiliki daya antiseptik dan antibakteri. Komponen asam dalam biji pinang ditentukan melalui metode fraksinasi eter. Pathak dan Mathur $^{19}$ menunjukkan bahwa komponen utama asam dalam biji pinang adalah asam laurik (19,5\%), miristik (46,2\%), palmitik $(12,7 \%)$, oleik $(6,2 \%)$, linoleik $(5,4 \%)$ dan hexadecenoik (7,2\%). Komponen asam lainnya adalah asam stearik, dekanoid dan monoetilenik. Kandungan gliserida utama adalah $56 \%$ trimyristin, dimyristin dan laurimyristinpalmitin, $30 \%$ hexadecenolauromysritin dan oleo-(linoleo) myristopalmitin serta $14 \%$ oleolinoleogliserid dan oleolinoleopalmitin. Ekstrak etanol biji pinang menunjukkan kemampuan oksidasi, anti radikal bebas dan aktivitas antihyaluronodase sehingga esktrak ini aktif dalam antiinflamasi dan antimelagonesis. d. Patogenesis kerusakan gigi oleh S. mutans Patogenesis perusakan gigi oleh $S$. mutans salah satunya adalah melalui kerja pembentukan glikokaliks untuk mensintesis glukan melalui enzim yang dihasilkan oleh bakteri ini, yakni glukosiltransferase. Hada et al dalam Lin et $a l^{3}$ menyebutkan bahwa senyawa pryocyanidins dalam biji pinang adalah salah satu komponen tanaman yang mampu menghambat glukosiltransferase. Dengan demikian patogenesis melalui jalur ini tidak terjadi. Dalam penelitiannya Lin $e t a l^{3}$ mengemukakan bahwa senyawa katekin diketahui memiliki afinitas terhadap protein. Hal ini dapat ditunjukkan melalui penurunan aktivitas antibakteri dalam teh lewat adanya serum (pengikatan protein sebesar 82\%). Kekhasan yang lebih dikenal sebagai astringent ini menimbulkan sensasi mouthfell saat minum teh. Dapat diperkirakan bahwa penghambatan glukosiltransferase dan amilase serta perlekatan S. mutans dimediasi oleh fimbria, fibril atau protein permukaan lainnya, mungkin saja didukung oleh interaksi antara epigalokatekin dan komponen terkait dengan 
protein-protein ini, yang menyebabkan terjadinya perubahan struktur tertier dan kehilangan fungsi protein. Sehingga dapat diduga bahwa dengan mengkonsumsi teh atau penggunaan ekstrak spesifik dari teh dapat menghambat atau mencegah perusakan gigi. Aktivitas glukosiltransferase $S$. mutans juga telah dilaporkan oleh Nezar et $a l^{20}$ tanin dan senyawa turunan polifenol diketahui dapat menghambat pembentukan glukan terutama water insoluble glukan (WIG) yang memiliki peranan besar dalam pembentukan plak serta sangat penting sebagai awal terjadinya karies pada permukaan gigi. Glukan adalah polimer glukosa yang disintesis oleh gluksiltransferase ekstraseluler. Rahim dan Khan ${ }^{17}$ melaporkan aktivitas anti perlekatan S. mutans pada permukaan gigi, hidrofibisitas dan sintesis glukan dalam ekstrak buah cengkih. Dilaporkan bahwa penghambatan perlekatan bakteri dapat terjadi akibat perubahan dalam penempelan awal S. mutans. Reseptor pada permukaan $S$. mutans berubah dengan adanya komponen dalam ekstrak yang menyebabkan penurunan kemampuan perlekatan. Penurunan aktivitas perlekatan sel bakteri akan merusak koloni bakteri. Hal ini dengan demikian akan mempengaruhi akumulasi plak. Hidrofobisitas merupakan salah satu ciri bakteri untuk menempel pada permukaan makhluk hidup ataupun tidak hidup. S. mutans lebih hidrofobik dibandingkan dengan spesies bakteri Streptococcus lainnya. Namun penelitiannya membuktikan bahwa hidrofobisitas S. mutans tidak berperan penting dalam perlekatan. Untuk menyokong terjadinya plak dalam jumLah besar, bakteri akan melakukan sintesis glukan ekstraseluler untuk membentuk matriks ekstraseluler. Plak yang tebal akan menciptakan lingkungan anaerobik. Pembentukan glukan oleh glukosiltransfrase diketahui dapat dihambat oleh senyawa dalam ekstrak buah cengkih. Susanti dalam Lapu dan Ngaro $^{21}$ menyebutkan bahwa fenolik dan terpenoid dapat menghambat pertumbuhan bakteri Vibrio alginolyticus, karena senyawa tersebut dapat berikatan dengan lipid dan protein yang merupakan komponen utama penyusun membran sel bakteri, sehingga menurunkan permeabilitas membran sel 
bakteri. Menurunnya permeabilitas ini dapat menghambat transport senyawa atau ion dari dan ke dalam sel melalui proses metabolisme, sehingga sel bakteri akan mengalami kekurangan nutrisi. Dengan demikian pertumbuhan bakteri akan terhambat dan pada akhirnya akan mati. Menurut Scalbert dalam Lapu dan $\mathrm{Ngaro}^{21}$, tanin dapat menghambat pertumbuhan bakteri dengan cara mengikat enzim ekstraseluler antara lain enzim selulosa yang berperan dalam mengkatalisis selulosa menjadi glukosa yang mudah diserap oleh sel sebagai sumber energi, enzim amilase yang beperan mengkatalisis amilum menjadi glukosa dan maltosa, enzim pektinase yang mengkatalisis pektin menjadi asam galakturonat. Dengan terikatnya enzim ekstraseluler ini oleh tanin maka aktivitas enzim akan terhambat sehingga proses metabolisme sel bakteri akan terganggu yang menyebabkan pengambilan nutrisi dan pertumbuhan bakteri akan terganggu. Hal ini dikuatkan oleh Scalbert dalam Harsyatuti ${ }^{13}$ yang menyatakan bahwa tanin yang terkandung dalam biji pinang berfungsi sebagai antibakteri dengan cara menghambat enzim yang dihasilkan oleh S. mutans, mengambil substrat pertumbuhan atau mengganggu metabolisme melalui penghambatan proses fosforilasi aktif pada $S$. mutans.

Asam lemak bertindak sebagai surfaktan anionik dan memiliki sifat antibakteri dan antifungal pada $\mathrm{pH}$ rendah, selain itu juga bersifat selektif terhadap bakteri gram positif dengan mekanisme utamanya pada struktur dan fungsi dinding dan membran sel bakteri. Komponen-komponen ini diduga merupakan faktor yang berpengaruh dalam ekstrak daun sirih. Penghambatan produksi asam berkaitan dengan proses glikolisis. Penurunan produksi asam dapat disamakan dengan penurunan kecepatan pertumbuhan bakteri. Asam lemak yang terkandung dalam ekstrak dapat berperan sebagai enzim glikolitik yang merupakan salah satu faktor yang berperan terhadap aktivitas antibakteri dalam ekstrak daun $\operatorname{sirih}^{22}$. Mekanisme kerja ekstrak biji pinang untuk menghambat perlekatan bakteri, pembentukan biofilm dan plak dengan adanya 
glukosiltransferase dan sukrosa dan

pembentukan asam yang melarutkan mineral-

mineral gigi tidak diketahui, karena uji mekanisme lanjutan dan uji fraksi tidak dilakukan. Penelitian ini hanya menunjukkan adanya respon penghambatan terhadap $S$. mutans oleh ekstrak biji pinang.

\section{Kesimpulan}

Ekstrak biji pinang terbukti efektif dalam menghambat bakteri S. mutans. Ekstrak etanol biji pinang lebih efektif dibandingkan dengan

\section{Daftar Pustaka}

1. Gupta, P.C and Ray, C.S. 2004. Epidemiology of Betel Quid Usage. Journal Ann Acad Med Singapore 33 (4) : 31-36

2. Miller and Hamilton. 2001. Anticariogenic Properties of Tea (Camellia sinensis). Journal Med. Microbial 50 : 229 - 302

3. Lin, J., A.R. Opoku,M. Geheb-Keler, A.D. Hutchings, S.E Treblance, A.K Juger, J van Staden. 1999. Preliminary Screening of Some Traditional Zulu Medical Plants for Anti Inflamatory and Antimicrobial Activities. Journal of Ethnopharmacology 68 : 267-274

4. Masduki, Imam. 1996. Efek Antibakteri Ekstrak Biji Pinang (Areca catechu) Terhadap S. Aureus dan E. Coli In Vitro. Cermin Dunia Kedokteran 109 : 21-23

5. Pratama, M.R. 2000. Pengaruh Ekstrak ekstrak air. Hal ini dibuktikan melalui KHM ekstrak etanol yang lebih kecil (0,005\%) dibandingkan ekstrak air (0,75\%). Keefektifan ini diduga karena adanya empat jenis senyawa dalam ekstrak etanol biji pinang.

\section{Acknowledgement}

Penelitian ini terlaksana atas bimbingan Dr. C.A. Seumahu, S.Si, M.Si dan Dr. A. Hiariej, Dra., MP dari Laboratorium Mikrobiologi FMIPA Biologi Universitas Pattimura serta bantuan dana dari Harian Kompas Indonesia.

Serbuk Kayu Siwak (Salvadora persica) terhadap Pertumbuhan Bakteri Streptococcus mutans dan Staphylococcus aureus

6. Sulaiman dan Darise Muchin. 2002. Fitokimia dalam Praktek, Penuntun Praktikum Asisten Fitokimia Lab Farmakognosi/Fitokimia. FMIPA Pancasakti. Makassar.

7. Laboratorium Kesehatan Provinsi Maluku, 2000. Panduan Penyiapan Medium dan Kultur Bakteri.

8. Standar of Procedure Laboratorium Mikrobiologi Farmasi. 2006. Universitas Hassanudin, Makassar

9. Standar of Procedure Kromatografi Lapis Tipis Laboratorium Kimia Dasar, 2006. Universitas Pattimura, Ambon

10. Abbas. Ghulam, S. Naqvi, S. Erum, S. Ahmed. A. Ur-Rahman, and A. Dar. 2012. Potential Antidepressant activity of Areca catechu nut via elevation of 
serotonin and noradrenalin in the hippocampus of rat. Phytother. Res. 27:39-45.

11. Joshi. Madhusudan, K. Gaonkar, S. Mangoankar and S. Satarkar. 2012. Pharmacological investigation of Areca catechu extracts for evaluation of learning, memory and behavior in rats. ICPJ 1(6):128-132.

12. Cyriac. Maria Bobby, V. Pai, I. Parghes, M. Shantaram, and M. Jose. 2012. Antimicrobial properties of Areca catechu (areca nut) husk extracts against common oral pathogens. IJRAP 3(1):8184.

13. Haryastuti, Dwi Aditya. 2012. Inhibisi ekstrak biji pinang terhadap pelepasan kalsium pada proses demineralisasi gigi yang distimulasi Streprococcus mutans. Skripsi. Universitas Jember. Jawa Timur.

14. Iftitah, Lailatul. 2005. Uji Daya Hambat dan Analisis KLT-Bioautografi Ekstrak Biji Jintan Hitam (Nigella sativa) terhadap Bakteri Streptococcus mutans. Skripsi. UNHAS. Makasar

15. Zhou, H. James. 2001. Composition and Method for Inhibiting Oral Bacteria.US $\begin{array}{llll}\text { Patent } & 20 . & 1 & \mathrm{hlm}\end{array}$ http://www.patentstorm.us/patent/63195 23-description.htmL.7 Maret 2007.

16. Rahim Abd and H.B.S. Khan. 2006. Comparative Study on The Effects of Crude Aqueous (CA) and Solvent (CM) Extracts of Cloves on The Cariogenic
Properties of Streptococcus mutans. Journal of Oral Science 48 (3) : 117-123

17. Saaroni dan Adjirnie. 2005. Spesifikasi Simplisia dan Ekstrak Etanol Biji Pinang Areca catechu asal Tawamangu serta Toksisitas Aku dan Khasiat Hemostatiknya pada Hewan Coba. 1 hlm.

http://www.litbang.depkes.go.id/media/i ndex.php?option $=$ content\&task $=$ view\&i $\mathrm{d}=67 \&$ itemid=31.9 Januari 2007

18. Pathak P.S and Mathur. S.S. 2006. Decomponent Acid and Glicerides of Areca Nut (Areca catechu) Fat. Journal of the Science of Food and Agriculture. 5(10) : 467-465

19. Nezar. Noor, Y. Nielsen amd N. Skaug. 2005. In vitro Effects of Crude Chat Extract on the Growth, Colonization and Glukosiltransferase of Streptococcus mutans. Acta Odontologica Scandinavia 63 : 136-142

20. Lapu, P. dan N.R. Ngaro. 2001. Pengaruh In Vitro Ekstrak Daun Nimba (Azadirachta indica) terhadap Bakteri Patogen Udang Windu (Vibrio alginolyticus). Journal Biosains 6(2) : 4953.

21. Naliha T dan Rahim A.H.Z. 2007. The Crude Aqueous Extract of Pier bettle. L. and its Antibacterial Effects towards Streptococcus mutans. American Journal of Biotechnology and Biochemistry $\mathbf{3}$ (1) : $10-15$ 